\title{
Policy Makers' Perspective on Impacts of Decentralizing Forest Management in Kenya on Forestry Conservation and Community Livelihoods
}

\author{
Musingo Tito E. Mbuvi \\ Kenya Forestry Research Institute, P. O Box 20412 - 00200. Malindi, Kenya \\ E-mail: mtembuvi@gmail.com; mtembuvi@hotmail.com \\ James B. Kungu \\ Department of Environmental Sciences, School of Environmental Studies \\ Kenyatta University, Nairobi, Kenya \\ E-mail: kungu.james@ku.ac.ke; kungu_james@yahoo.com
}

Received: December 26, 2019 Accepted: March 4, 2020 Published: June 28, 2020

doi:10.5296/emsd.v9i3.16136

URL: https://doi.org/10.5296/emsd.v9i3.16136

\begin{abstract}
Forests in Kenya were under traditional community management regimes up to 1891 when formal state management of forests started in Vanga Mangrove forest and later the entire country. In 1997 decentralized forest governance was successfully piloted through Participatory Forest Management in Kenya. This informed review of the Forests Act, Cap 385 to The Forests Act, 2005 subsequently revised to Forest Conservation and Management Act, 2016. The Act has explicit support to decentralized forest management with special focus on communities. The study determined the perceptions of policy makers on: why decentralization was introduced; policy makers' understanding of decentralization and its impact on forest management and community livelihoods. Literature review was conducted, questionnaires administered and Key Informant Interview and Focus Group Discussion held. The policy makers indicated that decentralization was being implemented in the country and they could distinguish the models being practiced and noted that decentralization was facilitating stakeholder participation and improving forest conservation and community livelihoods. The key challenges were; inadequate budgetary allocation; failure by state to transfer key functions to communities but had decentralized roles that reduce costs. The country has three forest management models and each was best in its context but can be
\end{abstract}


enhanced through capacity building, financial support and partnerships.

Keywords: Policy-maker, Impact, Decentralization, Governance, and perceptions

\section{Introduction (Forest Administration and Legislation)}

The shift in forest management from command and control to community participation in Kenya can be traced to the first forest legislation, in 1891 (Mbuvi \& Kungu, 2019), which focused on the protection of Mangrove swamps of Vanga Bay and was extended to protect Mangroves throughout the Coast in 1900 (Mugo, Nyandiga \& Gachanja, 2010). Prior to 1895, forest and natural resource use was controlled through a system of traditional rules \& regulations with no formal policy and were enforced by a council of elders through sanctions and fines. The Sessional Paper No. 10 of 1965 on African Socialism and its application to planning in Kenya (Government of Kenya [GoK], 1965b) was the first policy document to recognize the need to conserve natural resources for all future generations and expressed concern about the quality of the environment (Ongugo, Langat, Oeba, Kimondo, Owuor, Njuguna, Okwaro \& Russell, 2014). Despite absence of a policy progressive reservation of forests and meticulous conservation of forest resources continued until the Second World War. This led to displacement of local communities and/or their exclusion from access and usufruct rights to land, forests and forest resources.

At the end of the war, the government formed a development committee which had a forestry subcommittee tasked to consider what was the ultimate objective of forest policy. The subcommittee's report recommended planting of 6,000 acres per annum of exotic softwoods, in addition to reservation of protection forests and catchments. This report, directed the Department's work, until the forest policy of 1957 (White Paper no. 85) was published and revised in 1968 sessional paper no.1 (Mugo et al., 2010; Ongugo et al., 2014). Prior to this, the Forest Department (now Kenya Forest Service-KFS) followed the general recommendations of a succession of visiting experts who were sent to the Colony to advice on forest matters. Between 1902 and 1908 forestry activities were directed to the reservation of existing forests (Logie \& Jones, 1968), so far as they had been explored, the supply of fuel to the railway and the beginning of saw milling to supply timber for local use. Some exotic species were introduced to begin forest plantations both for railway fuel and for timber (Logie \&Jones, 1968; Mugo et al., 2010).

"The Forests of East Africa" by D.E. Hutchins and published in 1909 was a very impressive and far-sighted document, (Logie \& Jones, 1968) that guided work by the Forest Department for many years (Mugo et al., 2010). The document did not contain a precise statement of policy, it had good principles that have changed overtime to include emerging issues as outlined in Table 1 and a draft policy of 2020 (GoK, 2020). 
Table 1. Historical (1968 and 2015) profile of guiding parameters that have been used to develop the forest policy principles in Kenya

\begin{tabular}{|c|c|}
\hline White paper No. 85 of 1957 & Draft Forest policy of 2020 \\
\hline 1. Reservation of land for forest & 1. Public good \\
\hline purposes & 2. Ecosystem approach \\
\hline 2. Protection of forest estate & 3. Sustainable Forest Management (SFM) \\
\hline 3. Management & 4. Good governance \\
\hline 4. Industry & 5. Public participation \\
\hline 5. Finance & 6. Polluter and User Pays \\
\hline 6. Employment & 7. Commercialization of forestry activities \\
\hline 7. African areas & 8. Conservation of degraded and fragile ecological areas \\
\hline 8. Private forest and other forests & 9. Sustainable Consumption and Production (SCP) \\
\hline not under state ownership & 10. Research, education and knowledge \\
\hline 9. Public amenity & 11. Livelihood enhancement \\
\hline \multirow[t]{2}{*}{ 10. Wildlife Research and education } & 12. Indigenous knowledge and intellectual property rights \\
\hline & 13. International and regional cooperation \\
\hline
\end{tabular}

The Kenyan forestry sector has undergone extensive legislative and policy reforms in the past two decades that have fundamentally transformed the laws, regulations and institutions supported by diverse capacity building to participatory natural-resource governance (Mugo et. al, 2010). The policy formulated in 1957 which focused on conservation and management of forest resources on government land has been revised several times with the 2020 draft forest policy being the most current (KFS and MENR, 2007; GoK, 2020). The draft forest policy of 2020 (GoK, 2020) recognizes that forest has experienced poor performance and improving forest governance has been its explicit objective and complies with the national development agenda and The Constitution 2010 (GoK, 2010). Additionally, The draft forest policy appreciate the emerging opportunities for sustainable forest management and provides opportunity for the participation of strategic stakeholders in the conservation and management of forests while providing for shared responsibility for conservation and management of forests including protection and enforcement of regulations (KFS and MENR, 2007; GoK, 2010; GoK, 2020). The National Forest Programme (GoK, 2016a) recognizes that decentralization offers a solution to most of the challenges facing forest management. In this paper decentralization has been defined as any act in which a central government formally cedes powers to actors and institutions at lower levels in a political-administrative and territorial hierarchy (Adam \& Eltayeb, 2016).

\subsection{The Problem and Justification}

Forestry sector in Kenya has undergone four major legislative reforms: traditional community based forest management to Forest Act (CAP 385); repeal of Forest Act (CAP 385) to the Forests Act, 2005 which was supported by adequate consultations and expert guidance; repeal of Forest Act, 2005 to align with the Kenya Constitution, 2010 to Forest Conservation and Management (FCM) Act, 2016 (GoK, 1965a; GoK, 2016b) and the introduction of 


\section{Macrothink}

Environmental Management and Sustainable Development

ISSN 2164-7682

2020, Vol. 9, No. 3

decentralization in the forest sector through Participatory Forest Management (PFM). The constitution 2010 enacted in 2010 provides overarching support to devolution of forest resources and obligates the state to ensure that community benefit from natural resources and also the community are expected to participate in the management of the resource as noted by Barr, Wollenberg, Limberg, Anau, Iwan, Sudana, M. Moeliono, \& Boateng. (2001). Decentralization in forest governance was initiated as it was perceived that it could lead to better resource management because it promotes local participation, accountability at the level of resource users, and empowerment of communities as was noted by Monditoka (2011). The study was guided by three questions as outlined below to: determine the respondents understanding of decentralization in the forest sector and its effects on governance, forest management and livelihoods. The specific questions were: What factors led to introduction of decentralization in forest governance? What are the outcomes and contribution of decentralizing forest governance in Kenya and How can decentralized forest management be improved?

\section{Methodology}

\subsection{Study Site and Sample}

The study was undertaken in counties where forest decentralization was at different levels of implementation targeting 11 (Figure 1) out of the 47 counties. The counties included; Mombasa, Nyandarua, Nakuru, Nyeri, Kilifi, Taita Taveta, Narok, Kiambu, Kakamega, Kwale and Nairobi. Nairobi was selected because it was the capital city and the headquarters for all organizations and the senior policy makers for both government and NGOs were based. The surveys were done in field and headquarter offices for staff at policy making level involved in forestry management of national government and Non-Government Organization (NGOs) that included; Ministry of Forestry and Wildlife, Kenya Forest Service (KFS), Kenya Forestry Research Institute (KEFRI), Kenya Wildlife Service (KWS), National Environmental Management Authority (NEMA), Nature Kenya, Forest Action Network (FAN), IUCN-Eastern and Southern Africa Office Nairobi and WWF Kenya Office, National Community Forest Association (NACOFA) and county and station based community organizations. The professional representation of the policy maker respondents included: 1 conservation secretary, 3 Directors, 1 Senior Deputy Director, 3 Heads of Conservancies, 6 Ecosystem Conservators, 4 Assistant Directors ( 3 from KFS and 1 from KEFRI), 2 Research scientists, 2 lecturers, 6 heads of NGOs, 3 senior officers from the civil society and 5 Community Forest Association (CFA) chairpersons. The respondents were at policy making level or at management levels where they would influence development and implementation in the country. 


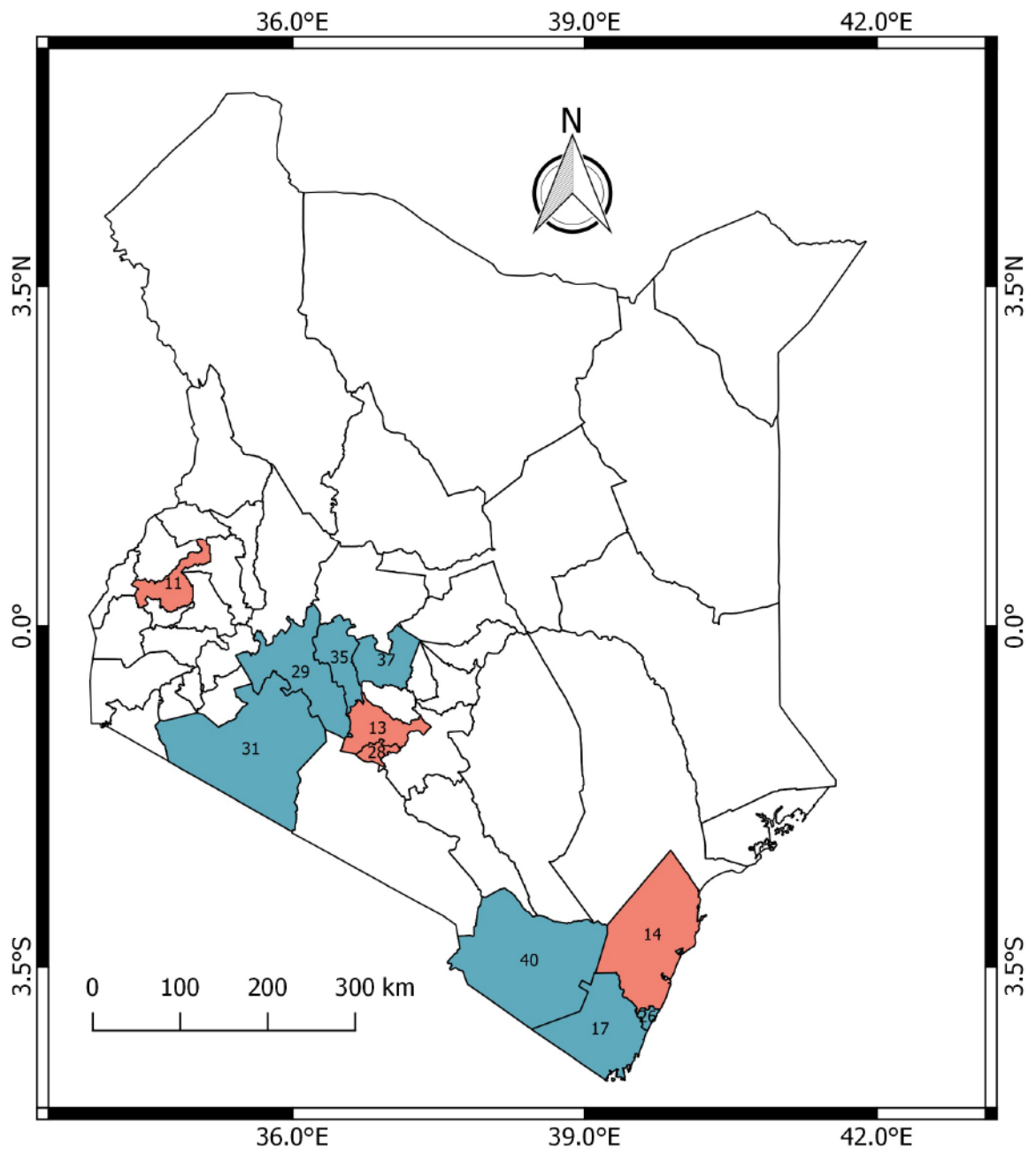

\section{Legend}

Longest Period of Implementation

Least Period of Im
\begin{tabular}{|l|l|}
\hline COUNTIES & CODES \\
\hline NYANDARUA & 35 \\
\hline NYERI & 37 \\
\hline TAITA TAVETA & 40 \\
\hline MOMBASA & 26 \\
\hline NAKURU & 29 \\
\hline NAROK & 31 \\
\hline KWALE & 17 \\
\hline
\end{tabular}

Figure 1. Study sites

\subsection{Sampling Design and Data Collection Methods}

The study used descriptive research design. Social science methods used included; literature review of policies and legislation, project documents and government documents on decentralization to understand how decentralization was implemented in different sectors especially how decentralization was undertaken in forestry in Kenya and in other countries. The policy and legislative instruments included Memorandum of Understandings (MoUs), policies, Acts, agreements and other forms of legislations. Focus Group Discussion (FGD) 
and Key Informant Interviews (KII) were conducted guided by a checklist.

Questionnaires were administered to thirty six policy makers from organizations (government, non-government and community) involved in forest management. The 36 policy maker respondents were drawn from $23 \%$ of the 47 counties of Kenya. The counties were divided into: counties with the oldest sites (where forest decentralized was started), counties where forest decentralization was startting and Nairobi which is the county hosting the capital city, headquarters of government ministries, most NGOs and civil society organization.

Majority (69\%) of the policy makers interviewed were over 40 years old, with $28 \%$ being above 50 years old and having over 25 years of work experience in forestry sector. This suggests that the respondents had adequate knowledge on forestry management and were very well conversant with policy issues. The policy maker respondents were predominantly male $(92 \%)$ with only two female respondents $(8 \%)$.

Fifteen Key Informant (KI) respondents with expert knowledge on the diverse issues of the research; policy, social and forest management were selected through purposive sampling and snow-balling approach (Mugenda \& Mugenda, 2003). The researcher through KII developed a list of officers to be interviewed based on officers' knowledge of forest decentralization. The interviewees were asked to propose further KIs they considered to have relevant experience, and these were added to the sample until no new names were mentioned. They were from relevant government departments as well as local and international non-governmental institutions involved in the management of forests and included: policy makers, retired officers and community leaders. Questionnaire was administered to 36 respondents. Five FGD of mixed sexes and age were held in each site (regime) and had between five and ten participants (Freitas, Oliveira, Jenkins \& Popjoy, 1998; Boateng, 2012) selected with help of KIs through purposive sampling (Mugenda \& Mugenda, 2003.

\subsection{Data Analysis}

The policy documents and project reports were analysed thematically (Braun \& Clarke 2006; Maguire \& Delahunt, 2017). Review of evolution of policy development in Kenya was done through analysis of factual information about, and justifications for, the different forest governance regimes. This was done in terms of how the regimes were designed in theory and how they were implemented in practice. Excel sheet was used to summarize and analyse the data and results presented in tables and graphs.

\section{Results and Discussion}

\subsection{Factors That Led to Introduction of Forest Decentralization in Kenya}

The three most important reasons why the Kenyan government started decentralization in forest management according to the policy makers were: the deterioration of forest conditions leading to inadequate resources, failure of Command and Control ( $\mathrm{C}$-and-C) approach leading to forest resource degradation and the global paradigm shift towards more inclusive management system (Table 2). These reasons are similar to those enumerated by Barr et al. (2001); Larson \& Soto (2008), where decentralization was initiated to improve resource 
allocation, efficiency, accountability and equity by linking the costs and benefits of public services more closely. Further, local management units at forest stations and CFAs know the needs and desires of the local communities than the national government. The process also provides an opportunity for holding the local leaders accountable; promote democracy by bringing the state closer to the people and increasing participation and building of social capital (Larson \& Soto, 2008).

Table 2. Factors considered by Policy makers to have led the Kenya government to initiate decentralization in forest management $(\mathrm{N}=36)$

\begin{tabular}{|l|r|}
\hline Factors that pushed government to initiate decentralization & Response (\%) \\
\hline Deterioration of forest conditions leading to inadequate resources & 23 \\
\hline Failure of Command and Control & 17 \\
\hline Pressure from partners (communities, Donor/Global community) & 17 \\
\hline Low participation of stakeholders in forest management & 10 \\
\hline Efficient forest conservation and community involvement & 10 \\
\hline $\begin{array}{l}\text { Devolution of power and responsibilities to Forest Conservation } \\
\text { Committees and CFAs }\end{array}$ & 10 \\
\hline Political interference & 4 \\
\hline Unresponsive policies and legislative framework & 3 \\
\hline $\begin{array}{l}\text { Kyoto protocol requiring governments to involve communities } \\
\text { in managing natural resources }\end{array}$ & 3 \\
\hline Global trend in other sectors and political establishment & 3 \\
\hline
\end{tabular}

The country is witnessing forestry sector reform as it what happened when Ordinances amendments were passed in 1949 and 1954, to fit in with constitutional changes taking place in the Colony at the time (Mugo et. al, 2010) as is the case with the Forest Conservation and Management (FCM) Act 2016 which has been aligned to The Constitution 2010 (GoK, 2010). The ordinance transferred responsibility for forestry from the Governor, first to a member of the Legislative Council and, in 1954, to a Minister (currently referred to as a Cabinet Secretary). Forest management was decentralized from the Governor (currently President) to the Minister. Further, the FCM Act, 2016 has more opportunities as it provides for the involvement of more stakeholders with the community being key (GoK, 2016a). Focus Group Discussion and KI agreed that it may have been necessary to have change on organizational structures in the forest sector for better policy making to bring improvements by reducing confusion or incoherent arrangements at both levels of government and how they relate with other stakeholders as was noted by Hallsworth, Parker \& Rutter (2011).

\subsection{Indicators That Signalled Start of Decentralization in Kenyas' Forest Sector}

The promulgation of The Forests Act, 2005 reviewed to The FCM Act, 2016, was indicated by $46 \%$ of the policy makers as the bold step that signalled the start of decentralization of governance in the forestry sector in Kenya. Conceptualization of PFM through community involvement in forest management was indicated by $15 \%$ of the respondents as one of the 
major steps in Kenya towards decentralization in forestry. Participatory Forest Management brought in more assistance through community participation to enhance staff gaps among other challenges. It is worth noting that the need for forest staff was noted in the Ordinances 1915 and 1916 that published recruitment and terms of service of Forest Guards (Mugo et. al, 2010). Other key steps are outlined in Figure 2. Introduction of Rural Afforestation and Extension Service (RAES) as well as District Focus for Rural Development 1974 and 1980s (Sigei, 1987; Rutten, 1990) respectively were an indication that decentralization in forestry has been a process that has been going on for a long time. Key Informant and FGD indicated that the Forest Ac, 2005 was well known due to adequate awareness created during the time of its enactment across the country as a follow up to a national outcry on forest degradation.

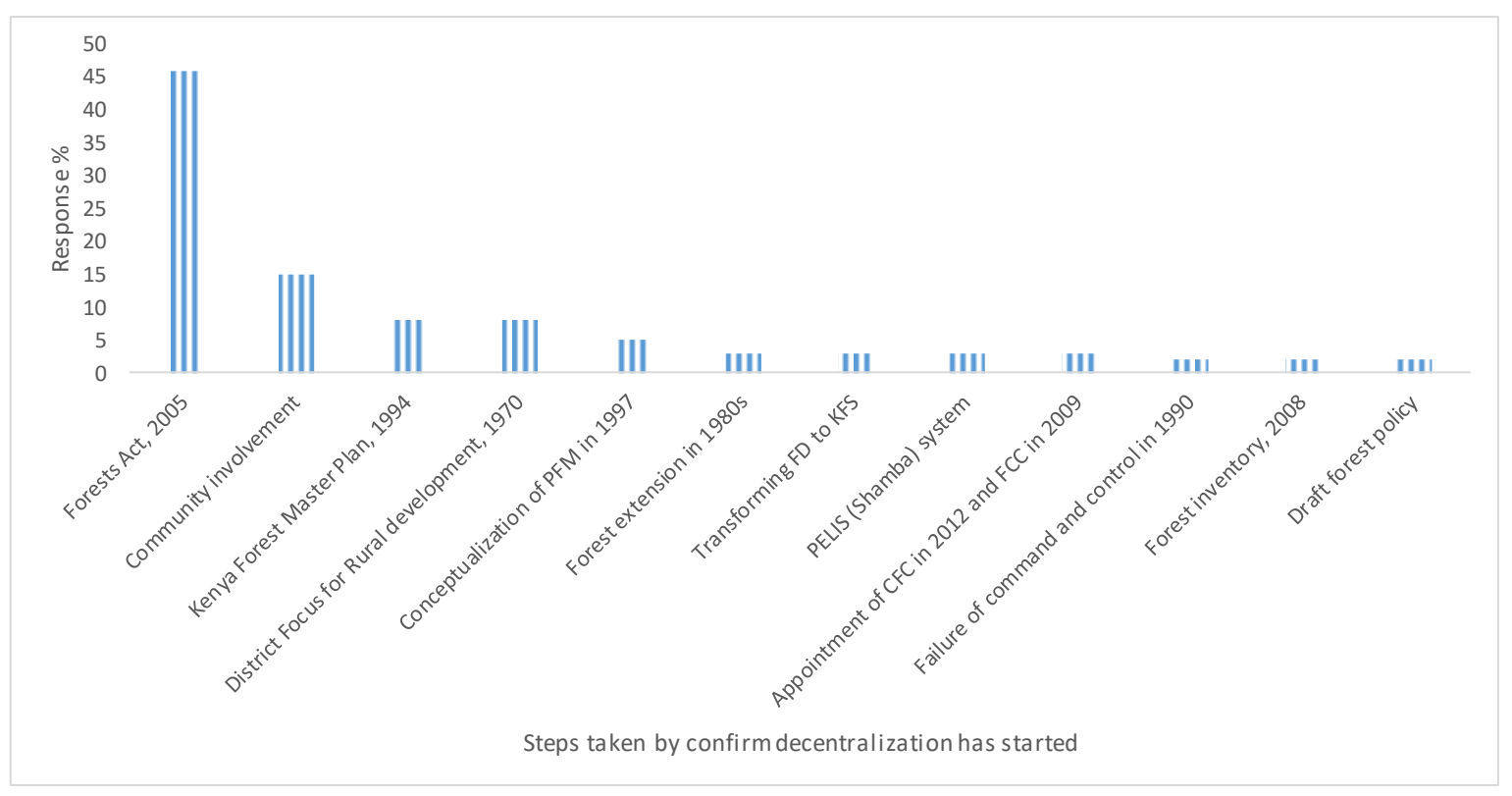

Figure 2. Proportion of policy-makers who mentioned different indicators of the start of decentralization in the forestry sector

The clarity of indicators of decentralization and recognition of outcomes further show policy makers are aware of the process, goal and expectations. These emerging strategies and initiatives further confirm commitment not only from the community but from the government, other partners and stakeholders. The communities indicated that delegation and de-concentration were the major decentralization types being implemented in the forest sector. As stated by Larson \& Soto (2008), forestry decentralization in Kenya was done to reduce costs, increase forest revenues, improve resource allocation, accountability, equity and sometimes increase control of local communities.

\subsection{Decentralized Forest Governance Types being Applied in Kenya}

Policy makers were aware that there was decentralization in the forest sector but were not very clear on the decentralization type being implemented as the study showed that; the policy makers could not distinguish between decentralization type (e.g. PFM), organizational 
structure created through decentralization (e.g. the CFA which is a requirement of the PFM process) and decentralization legislation in the forestry sector. This points to lack of clear understanding on what decentralization means by some policy makers. Participatory Forest Management related issues were indicated by $66 \%$ while political decentralization was only mentioned by one respondent (Table 3). These challenges may be mitigated through awareness creation, continuous capacity building and development of a national strategy to guide implementing of decentralization in the forest sector. This would avoid improper implementation due to misunderstanding leading to poor guidance of the process by the policy makers. This was noted by Court, Mendizabal, Osborne \& Young ( (2006) that limited understanding of policy process result to failure to engage in an effective manner, as a results, use evidence in an ineffective way and constraint their policy influence. Further, when Civil Society Organization (CSOs) in Kenya engaged parliament to change policy it failed as it was misguided and has had limited impact while it might have been more practical to engage different groups of policy makers (Court, et al., 2006).

Table 3. Decentralization types being implemented in Kenya $(\mathrm{N}=36)$

\begin{tabular}{|l|l|}
\hline Decentralization Types & Response (\%) \\
\hline Participatory Forest Management & 33 \\
\hline Community Forest Association & 18 \\
\hline Forest Conservation Committee & 15 \\
\hline $\begin{array}{l}\text { Administrative decentralization through formation of forest } \\
\text { zones and conservancy }\end{array}$ & 12 \\
\hline De-concentration (Decentralization of functions and not authority) & 6 \\
\hline $\begin{array}{l}\text { Management and protection of forests and woodlands } \\
\text { by County governments }\end{array}$ & 5 \\
\hline Forest (Charcoal) rules, 2009 & 3 \\
\hline $\begin{array}{l}\text { Fiscal decentralization-KFS given powers to raise and } \\
\text { retain financial resources }\end{array}$ & 2 \\
\hline Market decentralization-Tendering of materials to pre-qualified saw millers & 2 \\
\hline $\begin{array}{l}\text { Timber Manufactures Association-which encompasses Timber } \\
\text { harvesting regulations and prequalified saw millers regulation, 2009 }\end{array}$ & 2 \\
\hline Political decentralization & 2 \\
\hline
\end{tabular}

\subsection{Outcomes of Decentralizing Forestry Governance}

The policy makers were clear on outcomes of decentralization and the main outcomes of decentralized forest governance in Kenya were indicated to be increased access to forest resources by communities and community involvement in management (Table 4). This shows that they understand what decentralization is and were aware that decentralization was taking place in the forest sector. Further, the communities were aware of outcomes of decentralization including; increased exercising of the bundle of rights leading to increased access of resources, stakeholder involvement in decision making and access to information 
(Barr, et al., 2001; RRI, 2012).

Table 4. Outcomes of decentralized forest governance in Kenya $(\mathrm{N}=36)$

\begin{tabular}{|l|l|}
\hline Reasons & Response (\%) \\
\hline Increased access to forest resources by community & 16 \\
\hline Community involvement in forest management & 16 \\
\hline Increased access to information particularly on Forests Act 2005 (2016) & 11 \\
\hline $\begin{array}{l}\text { Improved management of the forest through tree planting, } \\
\text { rehabilitation and controlled utilization }\end{array}$ & 11 \\
\hline Local institutions involvement in making decisions & 11 \\
\hline Availability of credit to forest communities & 5 \\
\hline Promoting formation of social groups among forest communities & 5 \\
\hline Improved transport infrastructure linking communities with the forest & 5 \\
\hline Enhanced conflict management and resolution & 5 \\
\hline Resource allocation at regional and local forest management authorities & 5 \\
\hline $\begin{array}{l}\text { Presence of committee (with power to imposes fines and allow } \\
\text { for sustainable resource utilization) }\end{array}$ & 5 \\
\hline Existence of local governance systems & 5 \\
\hline
\end{tabular}

The findings of this study also showed that the formation of committees with power to impose fines and allow for sustainable resource utilization and allocation at regional and local forest management authorities and existence of governance at local level were of importance. It was also an indication that it will be easy for the community to assess the level of implementation of the decentralization process as shown by clarity on decentralization indicators and outcomes. The outcomes of decentralization in Kenya were in conformity with findings of Bazaara (2003), which indicated that devolution of decision making power over natural resources to publicly accountable local authorities is frequently advocated as a means of achieving social development and enhancing environmental management. Though the decentralization process was in its infancy, communities have shown that they were ready to participate in the process. This was evidenced by formation of local level organizations like CFAs, being allocated resources to determine their priorities and by the community showing competence by undertaking some forest management functions like controlling access to defined forest resources like firewood and grass. Furthermore, the community forest management organizations are forming alliances with several organizations and getting funding.

\subsection{Perceived Impact of Decentralized Forest Governance on Community Livelihoods and Conservation}

Policy makers (73\%) indicated that decentralization has greatly improved community livelihoods while $27 \%$ had a view that decentralization has not enhanced the livelihoods of local communities. The reasons given in support of improved community livelihoods were; improved access (got more products and have legal access) to forest goods and services 


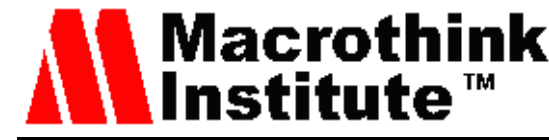

(47\%), enhanced income (30\%) and high food production (23\%) through Plantation Establishment Livelihoods Improvement Scheme (PELIS) and better conserved forest. There are several forestry livelihood activities that the policy makers attributed to implementation of decentralization, the key ones being; community participation in Income Generating Activities (33\%), PELIS (32\%), promoting community user rights (23\%) and sustainable access to timber and non-timber forest products (12\%). Despite these livelihood sources Adam and Eltayeb, (2015) concluded that forestry decentralization provides few direct mechanisms for lifting people out of poverty.

Broadly the majority of policy makers believed that decentralization has led to better forest conservation through: sustainable forest utilization leading to improved community livelihoods (37\%), communities being involved in decision making at all levels (33\%), reviving stakeholders trust like the composition of conservancy based Forest Conservation Committees (FCCs) (11\%), devolution of power and authority to lower management levels $(11 \%)$, devolved structures that have enhanced transparency and accountability (4\%) and increase in industrial forest plantation (4\%). The low value policy makers attach to industrial plantation may be a pointer to the notion that they are not part of the decentralization process but a pointer to a problem as highlighted by task report on forest resources management and logging activities in Kenya (GoK, 2018).

The policy makers indicated that decentralization led to improved forest management (Figure 3 ) with only $3 \%$ not being sure of the impact of decentralization on forest management.

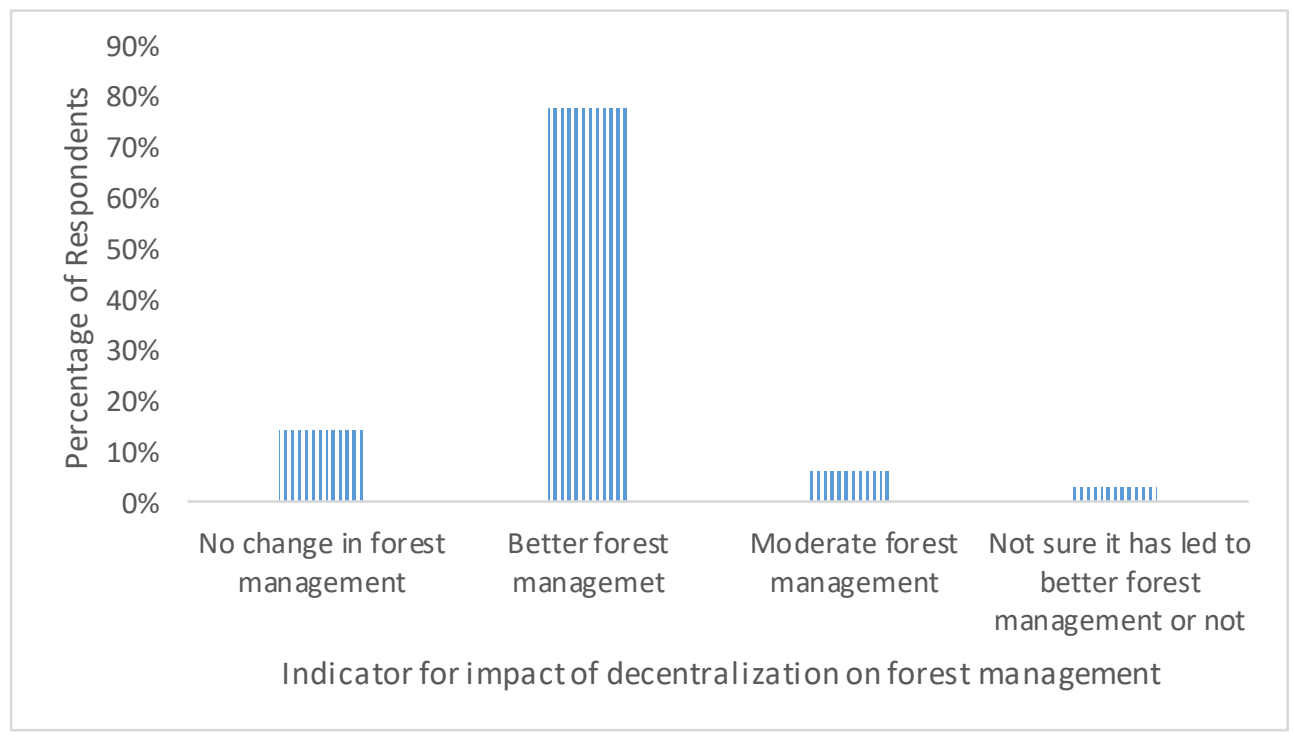

Figure 3. Policy makers perceived impact of decentralization on forest management

FGD and KI did not fully agree with the above situation as they noted that decentralization has not led to better forest management. This was attributed to limited powers devolved or being exercised by lower forest management levels such as FCC that have limited power for example in licensing and the minimal community participation in management through 


\section{Macrothink}

Environmental Management and Sustainable Development

ISSN 2164-7682

2020, Vol. 9, No. 3

community scouts. There is also poor national coordination of decentralization and that communities feel that the officers are still holding onto power and they are not benefiting from decentralization.

\subsection{Benefits of Decentralization in Forestry Sector}

The policy makers broadly perceived the benefits of decentralization to be improved natural resource management (22\%) and improved public participation (17.1\%). Table 5 provides the detailed benefits of decentralization in the forest sector.

Table 5. Benefits of decentralization in the forestry sector in Kenya $(\mathrm{N}=36)$

\begin{tabular}{|l|l|}
\hline Benefits of decentralization process in the forestry sector in Kenya & Response (\%) \\
\hline $\begin{array}{l}\text { Improving natural resource management leading to increased tree cover and } \\
\text { reduced forest destruction }\end{array}$ & 22.0 \\
\hline Improve public active participation (community and stakeholders in decision making) & 17.1 \\
\hline Minimal conflicts and less costs on enforcement & 10.2 \\
\hline Reduced cost incurred by central government in forest management & 8.8 \\
\hline Improved transparency and accountability & 5.8 \\
\hline Improved relations between state and community & 5.8 \\
\hline Improved understanding of responsibilities by various stakeholders & 5.8 \\
\hline Benefit sharing (avenues for community livelihood improvement) & 4.4 \\
\hline Enhanced community income & 4.4 \\
\hline Ownership of resources and responsibility levels of stakeholders enhanced & 2.9 \\
\hline Initiation of rural development & 2.9 \\
\hline Increase resources for forestry sector from government & 2.9 \\
\hline Wide-ranging pool of resources available to management & 1.4 \\
\hline Use of indigenous knowledge in conservation & 1.4 \\
\hline Increase donor confidence and support & 1.4 \\
\hline Devolved units of governance to lower levels & 1.4 \\
\hline Sustainability & 1.4 \\
\hline
\end{tabular}

The above enumerated policy makers positive perceptions of decentralization provide a foundation for institutionalizing decentralization as a management approach in forestry.

\subsection{Contribution of Decentralization to Forest Management}

The policy makers perceived the rating of overall effectiveness of decentralization on day to day forestry management in Kenya as not being very high with $45 \%$ rating it moderately, $22 \%$ high and $33 \%$ low. There was concern though that there may be differential implementation of decentralization in the country. It may be appropriate for forestry decentralization in Kenya to require an equalization fund as in Democratic Republic of Congo as noted by (Mbala \& Kasentry, 2010) as was indicated by $64 \%$ of the respondents indicating that legislation does not sufficiently take into consideration the livelihood differences between communities with $50 \%$ having as a similar perception in relation to forest type differences. This may lead to 
further marginalization of the poor and forest areas that require special interventions and negatively affect decentralization. It was important to recognize the poor require special legislation to support their participation like deliberate actions to provide support and access forest products as stated by Hobley (2007), that having pro-poor policies are meant to improve the assets and capabilities of the poor. This could be addressed through subsidiary legislation or through more elaborate review of FCM Act (GoK, 2016b). This study also concurs with a study by Khaunya, Wawire \& Chepng'eno (2015) that established that the county governments (devolution) in Kenya have made significant progress in involvement of stakeholders in decision making on development at the county level.

\subsection{Policy Makers' Perceived Comparison of Satisfaction Ranking with Decentralization Meeting its Decentralization Objectives Compared to Decentralization Achieving States' Objective for Decentralization in the Forest Sector}

The policy makers' opinion on how decentralization had achieved its objectives (judged from the principles of decentralization of participation, shared power, devolving power and authority, livelihood improvement, community access to resources etc.) in the forestry sector were varied, with government agencies showing very low satisfied level (Figure 4). The policy makers perceived that decentralization of forestry management being implemented are below the legal (states' objectives of reducing costs, assisting in forest management at no-cost to the government) expected threshold. The policy makers, government and quasi government agencies were satisfied with decentralization meeting states' objectives. In the contrarily, civil society, KWS, and FAN indicated a very low satisfaction status. KI discussions attributed this to decentralization failure to adequately address livelihood issues and enable communities participate in forest management and decision making. Further they perceived that the community are not benefiting neither being compensated for their efforts.

The community policy makers through KI indicated that decentralization had just started and anticipated to access benefits in future. The government policy makers perception that decentralization was meeting states objectives which differed with the civil society policy makers calls for need to develop a decentralization strategy to guide implementation, ensure that all needs and aspirations of all stakeholders are met and provide a uniform mode of evaluating progress of decentralization process. This may be a pointer to a scenario where the mode of decentralization was likely to be de-concentration and delegation where responsibilities are devolved to the field units but the headquarters retains the power and the civil society and communities are being assigned (by government) responsibilities with hardly any rights.

This situation may be pointing to a scenario where the communities are perceiving that decentralization is not addressing community needs or it implementation process has to be guided by the tenets of decentralization especially the government devolving functions to the community. The finding by non-state actors that they were lowly satisfied with decentralization meeting its objective was similar with decentralization experiences around the world that despite stated government commitments to decentralization, central governments and environment ministries resist transferring appropriate and sufficient powers 
to local authority (Ribot, 2002). Though the effectiveness of decentralization was rated low, despite being at its nascent phase, the government policy makers were satisfied with decentralization meeting its objectives and with the policy makers indicating that decentralization had improved forest governance points to a future forest management scenario under decentralized governance as was also noted about decentralization across all sectors (Cheeseman, Lynch \& Willis, 2016). Further, as was opined by KI and FGD and noted by Hallsworth, et al. (2011) there is need to have more emphasis on policy design and conception to help ensure that the planned actions represent a realistic and viable means of achieving the policy goals. This could be mitigated by improving policy making through creating synergy between theory and practice so as to provide the support required to turn desired practices into reality by including all stakeholders through adequate public participation and realizing that policy is the responsibility of all, and a product of their joint efforts (Hallsworth, et al. 2011).

During the survey, the policy makers, $(69.4 \%)$ were not satisfied with the current level community involvement in forest management. Key informant indicated that the government was benefiting but the others either losing or investing more into the process but not being adequately compensated. This was observed by Ribot (2002) that the reason was fear of losing economic benefits, including rent seeking opportunities, from the control they presently exercise over natural resources and the powers that define and support their political and administrative roles. Chomba, Nathan, Minang \& Sinclair (2015) indicated that in practice the state had devolved responsibilities to implement rules but not the discretionary powers to determine and change them, or sufficient financial incentives to implement them. Further, the scenario of multi-stakeholder participation was noted by (Monditoka, 2011) that forest governance was being shared between the central government, lower administrative levels, and CSOs but in Kenya the community is playing a bigger management role but enjoys least power and authority. There is need to ensure all stakeholders are satisfied with decentralization. 
Policy makers perceived level of decentralization achieving its objectives in the forestry sector

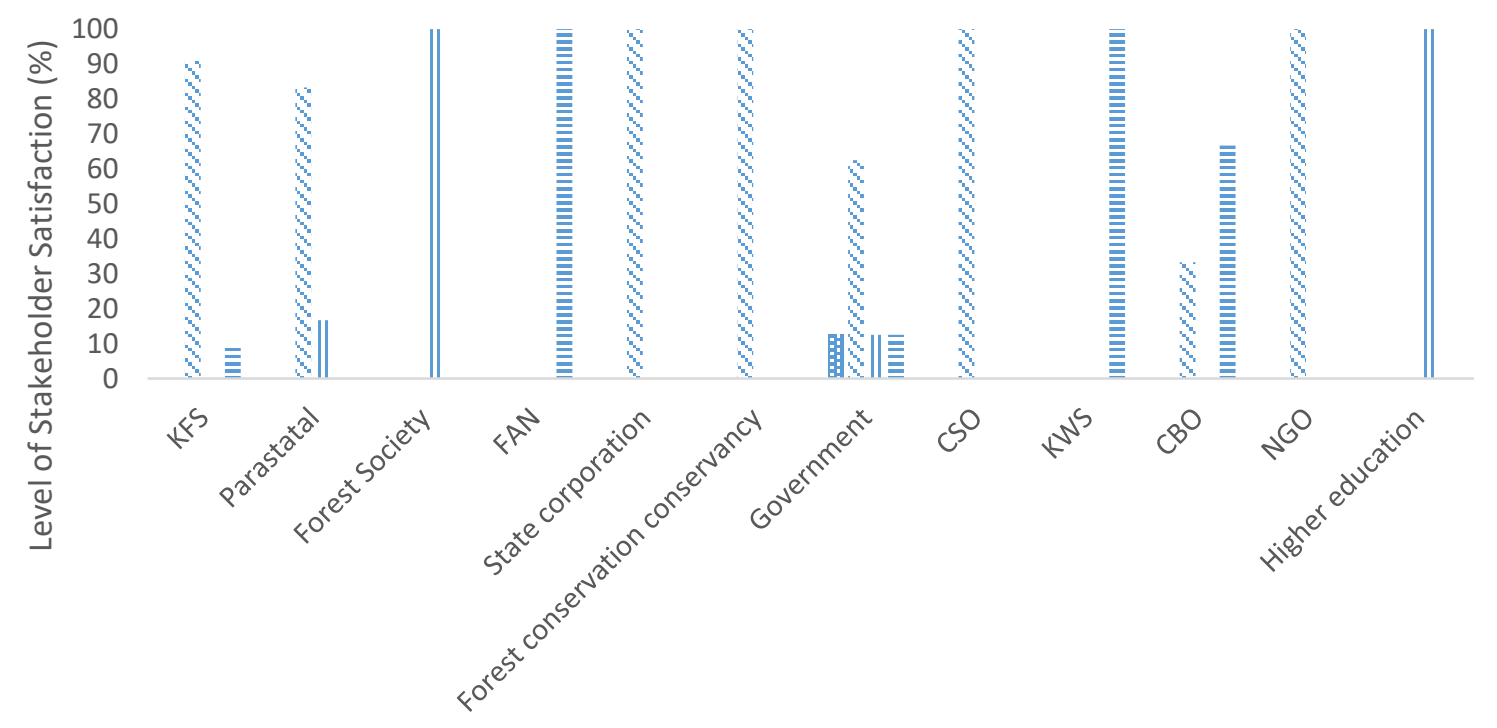

Policy makers perceived level of decentralizations' meeting the states objectives for decentralization in the forest sector

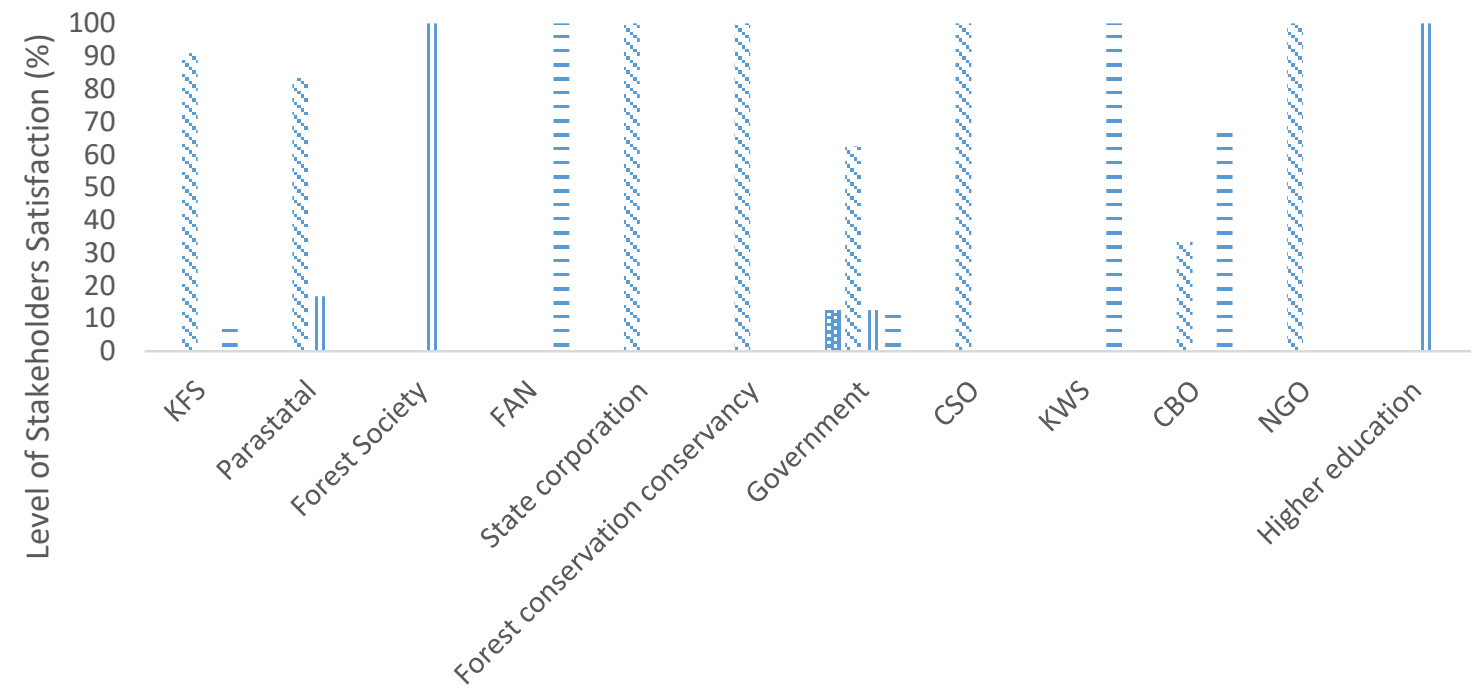

Stakeholders

嘈 Very satisfied satisfied III Low - Very low

Figure 4. Comparison of Policy makers perceived raking of level of satisfaction with decentralization process meeting its objectives and states' objective for decentralization in the forest sector $(\mathrm{N}=36)$ 


\section{Macrothink \\ Environmental Management and Sustainable Development \\ ISSN 2164-7682 2020, Vol. 9, No. 3}

\subsection{The Effect of Decentralizations on Forest Governance}

The results showed improvement in forest governance and accountability through four governance parameters as outlined in Figure 5.

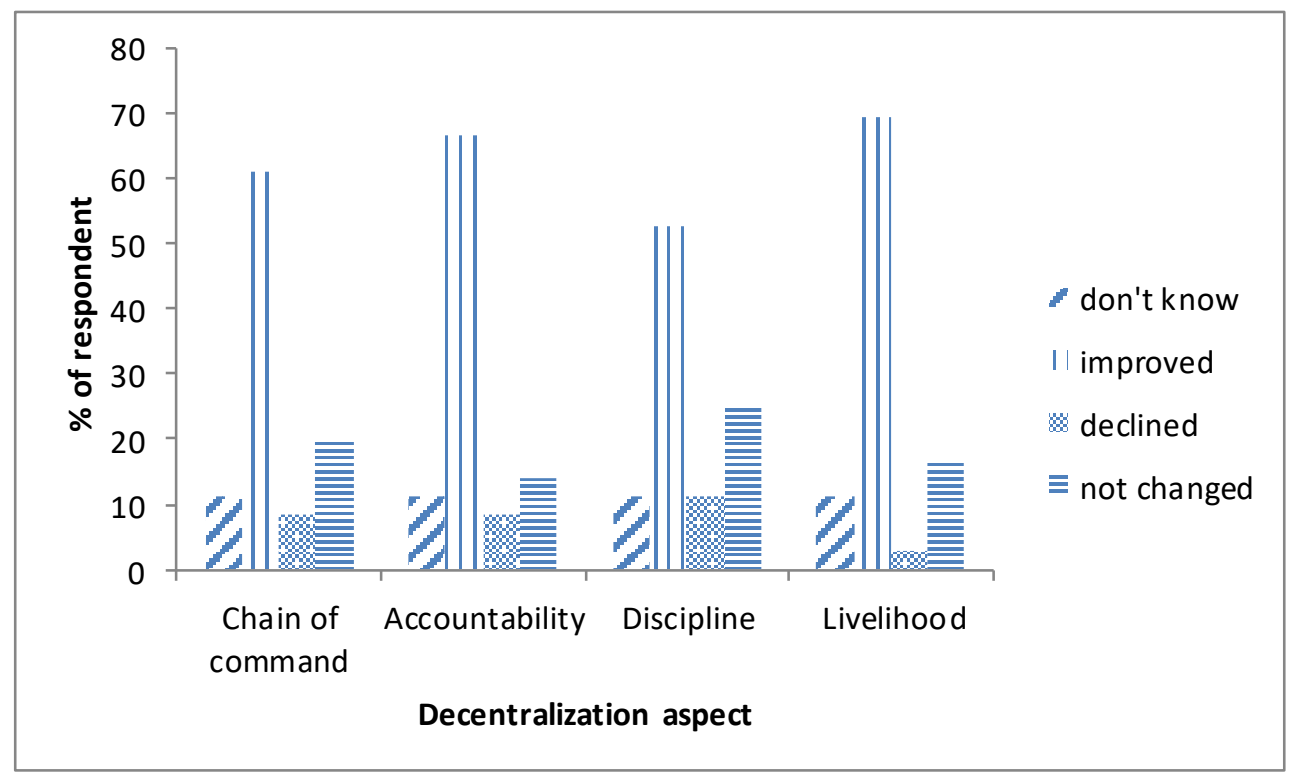

Figure 5. Policy makers' perceived impacts of decentralization on governance and livelihoods

Further, Policy makers indicated that forestry decentralization had improved forest governance through enhanced community access to resources (27\%), participation in legislation making (23\%), and participation in management decisions $(22 \%)$ and increased access to information (23\%) (Figure 6). Most researchers agree that positive outcomes in a decentralized environmental-governance framework rely on local governments being downwardly accountable to resource users as noted by Agrawal \& Ribot (1999). The only challenge which may frustrate the process in Kenya was that $50 \%$ of the respondents indicated that decentralization was not accompanied by adequate budget support. This may consequently slow down the decentralization process in Kenya. 


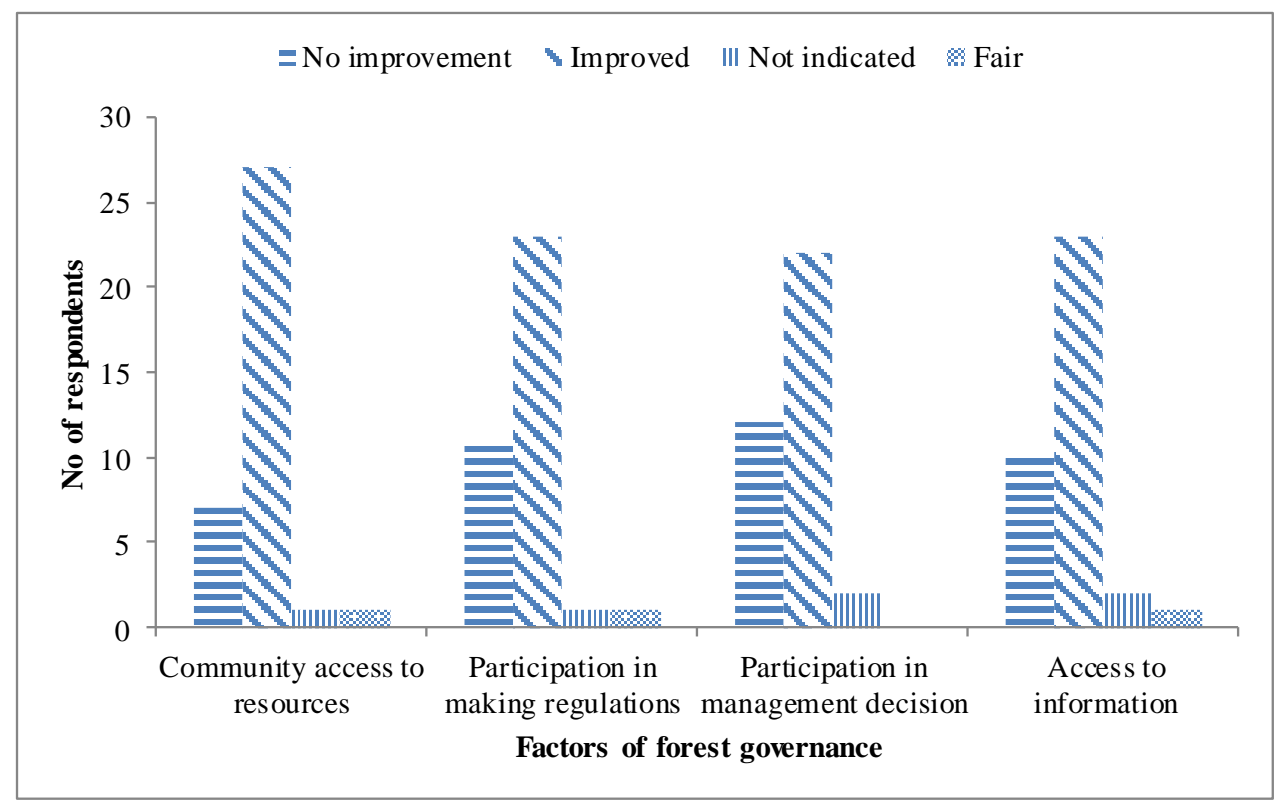

Figure 6. Policy makers perceived ranking of effects of decentralization on forest governance aspects $(\mathrm{N}=36)$

\subsection{How to Improve Forest Decentralization in Kenya}

The PFM decentralization model was proposed to be the best (appropriate) form of forest management as indicated in Figure 7. It ensures: communities, the State and other stakeholders are managing jointly; sustainable forest resources utilization; improved rural people's livelihoods and tenets of decentralization in the forestry sector of better forest management and improved community livelihoods are achieved. This perception was noted by Cheeseman et al. (2016) that that decentralisation was believed to bring more resources to the grassroots' level and ensures more equitable distribution.

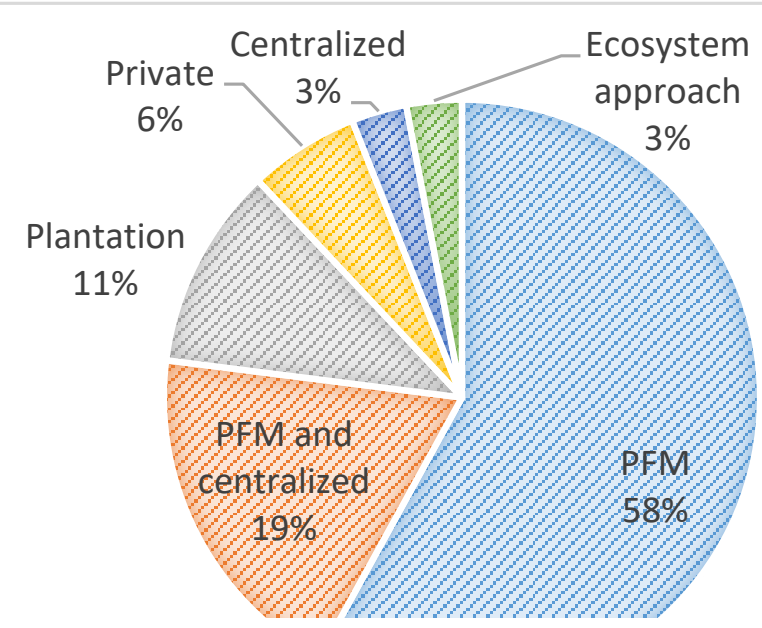

Figure 7. Policy makers perceived best forest management approach 


\section{MInstitute Macrothink $_{\text {Ins }}$}

Environmental Management and Sustainable Development

ISSN 2164-7682

2020, Vol. 9, No. 3

The PFM regime is feasible in all management regimes as was noted by Oldekop, Holmes, Harris \& Evans (2015). It ensures that: stakeholders participate in forest management, livelihood improvement; advocates that there should be no calling for the transfer of all decisions over natural resources to local populations or any one stakeholder but all should participate; advocate for subsidiarity so that the most appropriate lowest level for any given decision has the right to provided that making the decision at this level does not negatively impact the greater common good; promotes a sense of forest resources ownership among the communities; reduces conflicts between government and the community and does not allow for the 'tragedy of commons' scenario

\section{Conclusion}

The policy makers had adequate knowledge and experience on forest management and policy issues relating to forest management and were aware there is decentralization in the forest sector in Kenya. It was evident that the government started decentralizing forest governance due to deteriorating forest condition, community demanding for participation in forest resource management due to democratization process that were taking place in the country in the 1980s. The enactment of The Forests Act 2005 (reviewed to Forest Conservation and Management Act, 2016) signalled the start of decentralization, and was anchored in supreme law, constitution 2010, this was strengthened by the reforming of KFS and supported by NGOs, community and development partners. Participatory Forest Management was the main model of decentralization being applied in the forest management in the country. The policy maker's clarity on indicators and outcomes of decentralization are a basis upon which the process would be taken up and applied throughout the forest management sector and adapted for implementation in other natural resources. Further, the perceived positive impacts of decentralization ranging from improved conservation, increased revenue and improved community livelihoods encourage the government, community and other stakeholders to embrace decentralized forest governance. This was supported by perception by policy makers that decentralisation was bringing in more resources to the grassroots' level and ensuring more equitable distribution. Further, the government policy makers were satisfied with decentralization meeting its objectives and with the policy makers indicating that decentralization had improved forest governance points to a future forest management scenario under decentralized governance in Kenya. The non-state actors requested for more resources to enhance decentralization implementation at local level.

\section{Acknowledgement and Sponsoring information}

The authors of this paper acknowledge and appreciate support provided for this research from Government of Kenya through KEFRI research grants.

\section{Reference}

Adam, Y. O., \& Eltayeb, A. M. (2016). Forestry decentralization and poverty alleviation: A review. Forest Policy and Economics, 73, 300-307.

https://doi.org/10.1016/j.forpol.2016.05.009wn.run/

Agrawal, A., \& Ribot, J. C. (1999). Accountability in decentralization: A framework with 
South Asian and West African Cases. World Resources Institute, Institutions and Governance Program, Washington DC, USA.

Barr, C., Wollenberg, E., Limberg, G., Anau, N., Iwan, R., Sudana, I. M., Moeliono, M., \& Boateng, W. (2012). Evaluating the Efficacy of Focus Group Discussion (FGD) in Qualitative Social Research. International Journal of Business and Social Science, 3, 1-4. [Online] Available: http://ijbssnet.com/journals/Vol_3_No_7_April_2012/6.pdf

Bazaara, N. (2003). Decentralization, politics and environment in Uganda. Environmental governance in Africa Working papers: WP \#7 World Resources Institute. Washington DC, USA.

Braun, V., \& Clarke, V. (2006). Using thematic analysis in psychology. Qualitative Research in Psychology, 3(2), 77-101. https://doi.org/10.1191/1478088706qp063oa

Cheeseman, N., Lynch, G., \& Willis, J. (2016). Decentralisation in Kenya: the governance of governors. Journal of Modern African Studies, 54(1), 1-35.

https://doi.org/10.1191/1478088706qp063oa

Chomba S. W., Nathan, I., Minang, P. A., \& Sinclair, F. (2015). Illusions of empowerment? Questioning policy and practice of community forestry in Kenya. Ecology and Society, 20(3), 1-11. http://dx.doi.org/10.5751/ES-07741-200302

Court, J., Mendizabal, E., Osborne, D., \& Young, J. (2006). Policy Engagement: How civil society can be more effective. ODI. London UK. [Online] Available:

https://www.odi.org/sites/odi.org.uk/files/odi-assets/publications-opinion-files/200.pdf

Freitas, H., Oliveira, M., Jenkins, M., \& Popjoy, O. (1998). The Focus Group, a qualitative research method. ISRC, Merrick School of Business, University of Baltimore (MD, EUA), WP ISRC No. 010298. [Online] Available:

http://gianti.ea.ufrgs.br/files/artigos/1998/1998_079_ISRC.pdf

Government of Kenya. (1965a). African socialism and its application to planning in Kenya. Sessional paper No: 10 of 1965. Nairobi, Kenya: Government Printer.

Government of Kenya. (1965a).The Forest Act (Cap 385) of the laws of Kenya. Revised Edition 1982 (1962) Government Printer, Nairobi. Kenya.

Government of Kenya. (2010). The Constitution of Kenya 2010. Nairobi, Kenya: Government Printer.

Government of Kenya. (2020). Forest Policy. Ministry of Environment and Forestry. Government Printer, Nairobi. Kenya.

Government of Kenya. (2016a). National forest programme (2016-2030). Ministry of Environment and Natural Resources. Nairobi, Kenya: Government Printer.

Government of Kenya. (2016b). The Forest Conservation and Management Act, 2016. Kenya Gazette Supplement No. 155 (Acts No. 34). Nairobi, Kenya: Government Printer. 
Government of Kenya. (2018). A Report on forest resources management and logging activities in Kenya; Findings and recommendations Taskforce to inquire into forest resources management and logging activities in Kenya. Ministry Of Environment and Forestry Nairobi, Kenya

Hallsworth, M., Parker, S., \& Rutter, J. (2011). Policy Making in the real world: Evidence and Analysis. Institute for Government. UK.

Kenya Forest Service \& Ministry of Environment and Natural Resources (2007). Forest Law Enforcement and Governance in Kenya. A paper prepared for the East African Community-led Regional process in the framework of the Ministerial declaration, Younde, Cameroon, October 162003 on the Africa Forest Law Enforcement and Governance (AFLEG). Government of Finland, World Bank and World Conservation Union (IUCN).

Khaunya, M. F., Wawire, B. P., \& Chepng'eno, P. (2015). Devolved Governance in Kenya; Is it a False Start in Democratic Decentralization for Development?. International Journal of Economics, Finance and Management, 4(1). 1-11

Larson, A. M., \& Soto, F. (2008). Decentralization of natural resource governance regimes. Annual Review of Environment and Resources, 33, 213-239.

https://doi.org/10.1146/annurev.environ.33.020607.095522

Logie, J. P. W., \& Jones, G. A. (1968). Land use planning for forestry in Kenya. East African Agricultural and Forestry journal, 33(sup1), 59-62.

https://doi.org/10.1080/00128325.1968.11665294

Maguire, M., \& Delahunt, B. (2017). Doing a Thematic Analysis: A Practical, Step-by-Step Guide for Learning and Teaching Scholars. All Ireland Journal of Teaching and Learning in Higher Education, 8(3), 1-14. [Online] Available:

http://ojs.aishe.org/index.php/aishe-j/article/view/335

Mbala M. S., \& Kasentry, A. (2010). Forest Revenue Decentralization and Profits in Redistribution in the Democratic Republic of Congo in German. L. A. Karsentry \& A. Tiani, (Eds.), Governing Africa's Forests in a Globalized World. Earth scan, London UK.

Mbuvi, M. T. E., \& Kungu, J. B. (2019). Institutional Factors Influencing Decentralised Forest Governance: Policy Makers' Perspectives and Future Trends. Environmental Policy and Law, 49(4-5), 264-276. https://doi.org/10.3233/EPL-190173

Monditoka, A. K. (2011). Decentralized Forest Governance - A Policy Perspective. Centre for Economic and Social Studies. Working Paper No. 93. RULNR Working Paper No. 8. Begumpet, Hyderabad. India.

Mugenda, O. M., \& Mugenda, A. G. (2003). Research methods: Qualitative and quantitative approaches. African Centre for Technology Studies, Nairobi, Kenya.

Mugo, E., Nyandiga, C., \& Gachanja, M. (Eds.). (2010). Development of Forestry in Kenya (1900-2007): Challenges and Lessons Learnt. Kenya Forest Working Group, Nairobi Kenya. 


\section{Macrothink}

Oldekop, J. A., Holmes, G., Harris, W. E., \& Evans, K. L. (2015). A global assessment of the social and conservation outcomes of protected areas. Conservation Biology, 30(1), 1-9. https://doi.org/10.1111/cobi.12568

Ongugo, P. O., Langat, D., Oeba, V. O., Kimondo, J. M., Owuor, B., Njuguna, J., Okwaro, G., \& Russell, A. J. M. (2014). A review of Kenya's national policies relevant to climate change adaptation and mitigation: In from Mount Elgon. Working Paper 155. Bogor, Indonesia: CIFOR. Retrieved on 17th September sights 2018.

Ribot, J. C. (2002). Democratic decentralization of natural resources: Institutionalizing popular participation. World Resources Institute. https://doi.org/10.1057/9781403981288_6

Rights and Resources Initiative. (2012). What rights? A comparative analysis of developing countries' national legislation on community and indigenous peoples" forest tenure rights. Washington DC, USA.

Rutten, M. (1990). The district focus policy for rural development in Kenya: The decentralization of planning and Implementation, 1983-9. Edit Simon, D. in Third World Regional Development - a reappraisal. Paul Chapman Publishing.

Sigei, F. K. (1987). The District Focus for Development Strategy in Kenya: A case of Decentralization and the Changing Role of the Generalist Field Administration University of Nairobi. Unpublished Msc Thesis.

\section{Copyright Disclaimer}

Copyright for this article is retained by the author(s), with first publication rights granted to the journal.

This is an open-access article distributed under the terms and conditions of the Creative Commons Attribution license (http://creativecommons.org/licenses/by/4.0/). 